\title{
Bronchopulmonary 'Pseudo' Sequestration
}

\section{Bronkopulmoner 'Psödo' Sekestrasyon}

Nur Erik', Şeyma Başlılar', Sedef Kaya', Bengü Şaylan²

\section{Abstract}

The term "pulmonary sequestration" refers to a wide spectrum of bronchopulmonary vascular malformations. In this case report, we present an asymptomatic case with a normal right lower lobe supplied by a branch of the celiac artery. A 23-year-old male member of the military applied for a periodical physical examination. A thorax computerized tomography (CT) scan revealed a normal right lung volume, although the right lower lobe received its blood supply from the celiac artery. A diagnosis of a congenital pseudosequestration was made, and the patient was advised to seek treatment should pulmonary symptoms develop. Bronchopulmonary sequestration was first described by Pryce, who distinguished between three types of developmental abnormality: Type I: A normal lung with anomalous systemic arterial supply, Type II: An anomalous artery supplying a disconnected lung and an adjacent normal lung, and Type III: A nonfunctional and abnormal lung with systemic arterial blood supply. Later, the Pryce Type I sequestration was renamed 'pseudosequestration'. Congenital pseudosequestration is usually seen the in the lower lobes, and anomalous systemic blood supply arises from the descending thoracic aorta, celiac trunk or abdominal aorta. CT is the best diagnostic method.

Key words: Pseudosequestration, congenital, vascular malformation.

\section{Özet}

Bronkopulmoner sekestrasyon terimi geniş bir bronkopulmoner vasküler malformasyon spektrumunu içerir. Çölyak arterin dalından kanlanan, normal sağ akciğer alt lobu olan asemptomatik bir olguyu sunuyoruz. Yirmi üç yaşında asemptomatik, sigara içmeyen, erkek askeri personel rutin sağlık kontrolü için başvurdu. Kontrastlı toraks bilgisayarlı tomografisinde (BT) sağ akciğer alt lobun kanlanmasını çölyak arterden aldığı tespit edildi. Konjenital bronkopulmoner psödosekestrasyon olarak değerlendirildi ve solunum semptomu olursa başvurması önerildi. Bronkopulmoner sekestrasyon tanımı Pryce tarafından yapılmış ve üç grupta toplanmıştır. Tip I: Normal bir akciğer lob/segmentinin anormal sistemik kanlanmasının olması, Tip II: Akciğerden bağımsız olan akciğer dokusu ve komşu normal akciğerin anormal sistemik kanlanmasının olması, Tip III: Normal trakeobronşiyal sistemden bağımsız olan işlevsiz akciğer dokusunun anormal sistemik kanlanmasının olmasıdır. Daha sonra Pryce Tip I sekestrasyon 'psödosekestrasyon' olarak adlandırılmıştır. Konjenital psödosekestrasyon en sık alt loblarda görülür ve kanlanma desendan torasik aorta, çölyak arter veya abdominal aortanın bir dalından kaynaklanır. Tanıda BT en iyi yöntemdir.

Anahtar Sözcükler: Psödosekestrasyon, konjenital, vasküler malformasyon.

'Department of Chest Diseases, University of Health Sciences, İstanbul ' 'Sağlık Bilimleri Üniversitesi, i̇stanbul Ümraniye Eğitim ve Ümraniye Training and Research Hospital, İstanbul, Turkey Araştırma Hastanesi, Göğüs Hastalıkları Kliniği, İstanbul

${ }^{2}$ Department of Chest Diseases, University of Health Sciences, İstanbul Sultan Abdülhamid Han Training and Research Hospital, istanbul, Turkey

${ }^{2}$ Sağlık Bilimleri Üniversitesi, İstanbul Sultan Abdülhamid Han Eğitim ve Araştırma Hastanesi, Göğüs Hastalıkları Kliniği, Istanbul

Submitted (Başvuru tarihi): 01.04.2019 Accepted (Kabul tarihi): 14.06.2019

Correspondence (iletişim): Seyma Başlılar, Department of Chest Diseases, University of Health Sciences, İstanbul Ümraniye Training and Research Hospital, i̇stanbul, Turkey 
The term "pulmonary sequestration" is usually used to refer to a non-functioning lung with an anomalous blood supply, but can be linked to a wide spectrum of bronchopulmonary vascular malformations. We present here an asymptomatic case with a normal right lower lobe supplied by a branch of the celiac artery. This condition has previously been referred to as Pryce Type I bronchopulmonary sequestration, but new terminologies such as 'pseudosequestration' and bronchopulmonary vascular malinosculation are also present in literature.

\section{CASE}

A 23 year-old-male member of the military applied for a periodical physical examination. A chest $\mathrm{X}$-ray revealed left hilar enlargement and a reduction in volume of the right lung (Figure 1), and the patient was subsequently evaluated with contrasted computerized tomography (CT). A thorax CT scan (Figure 2 and 3) revealed normal volume in the right lung, although the right lower lobe was supplied with blood from the celiac artery. The patient was a non-smoker, asymptomatic and healthy, with no self-reported history of lower respiratory tract infection or hemoptysis, and the rest of his medical history was insignificant. A congenital bronchopulmonary vascular malformation diagnosis of bronchopulmonary sequestration Pryce Type I or pseudosequestration was made, and the patient was advised to seek treatment in the event of the development of pulmonary symptoms.

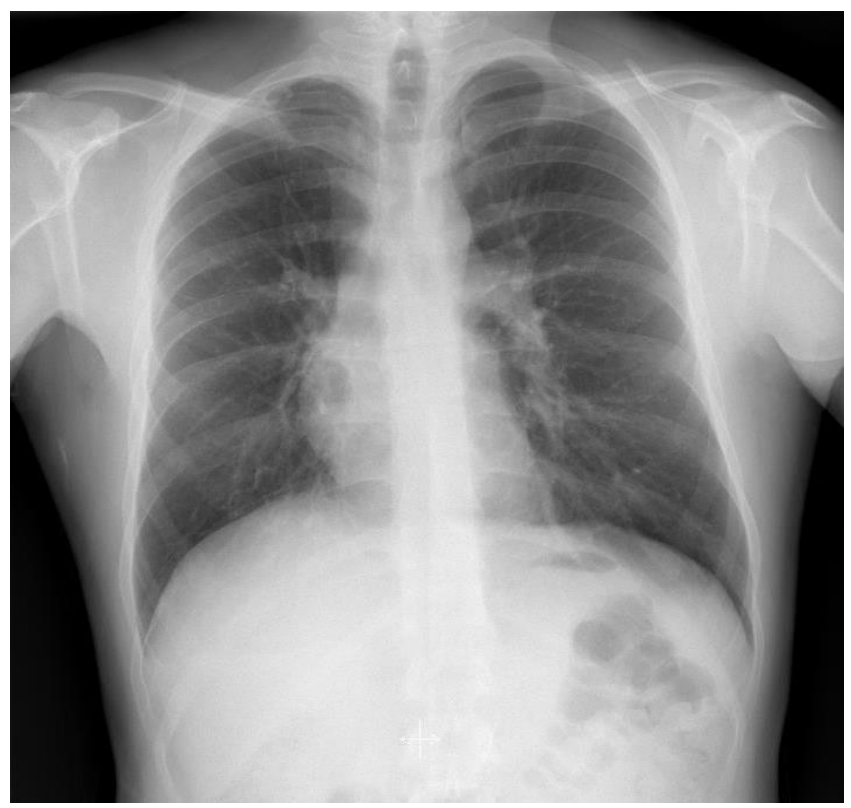

Figure 1: Posteroanterior Chest $X$-ray of the patient

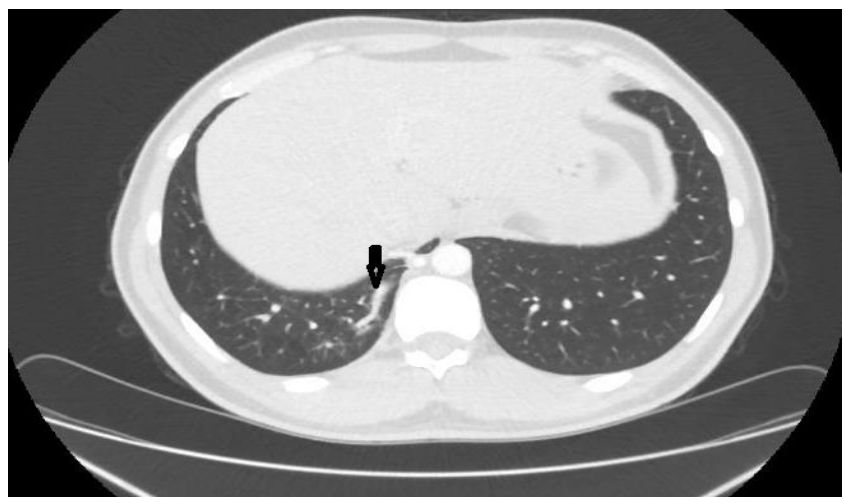

Figure 2: CT scan of the patient

\section{DISCUSSION}

Congenital bronchopulmonary vascular malformations include a broad spectrum of disorders (1-9). Bronchopulmonary sequestration was first described by Pryce (1) in 1946, who reported on an abnormal lung that was disconnected from the normal bronchial tree and that had an anomalous systemic blood supply. His classification for this congenital malformation included three developmental abnormalities: Pryce Type I: A normal lung with anomalous systemic arterial supply, Pryce Type II: An anomalous artery supplying a disconnected lung and an adjacent normal lung, and Pryce Type III: A nonfunctional and abnormal lung with a systemic arterial blood supply. Later the sequestration term replaced the Type III term. Sade et al. (2) made a new classification for pulmonary sequestration, related congenital bronchopulmonary vascular malformations and anomalous systemic blood supply to part of a normal lung, coining the term "pseudosequestration" $(2,3)$. In cases of pseudosequestration there is an aberrant supply to a lobar segment of the lung (usually right/left lower lobe) in the absence of a normal pulmonary blood supply (3-6). The lung shows normal communication with the tracheobronchial tree, and is more commonly reported in the left lower lobe where the blood supply is from an artery branching from the descending thoracic aorta. In cases of pseudosequestration of the right lower lobe, the blood supply usually arises from the celiac trunk or abdominal aorta $(4,5,9)$, although in our case, the right lower lobe received its blood supply from the celiac artery. Finally the term "malinosculation" (mal: abnormal, in: in, osculation: mouth) was coined by Clements and Warner (3) to define congenital bronchopulmonary vascular malformations. The term "pulmonary malinosculation" refers to the congenitally abnormal communication of one or more components of the bronchopulmonary vascular complex by means of small openings. Under this classification, a 
normal bronchopulmonary airway with an anomalous, aberrant arterial supply is referred to as a bronchoarterial pulmonary malinosculation $(3,11)$. The development of this malformation is explained as follows: the arrest of pulmonary artery growth for some reason during the development of the bronchial tree results in a lack of pulmonary blood supply. As a result, the developing bronchial branch is supported by vessels retained from the normally regressing systemic capillary network. In time, these vessels provide a systemic supply to part of normal lung. Such an anomalous blood supply to a normal part of lung has been demonstrated by Boyden (12) in an embryo.

Pseudosequestration may be congenital, or may be a consequence of such acquired diseases as bronchiectasis, pulmonary tuberculosis, pulmonary infection, pulmonary thromboembolism or chronic obstructive pulmonary disease. In acquired cases, the patient is frequently symptomatic with fever, cough or hemoptysis. Diagnosis can be made via a digital subtraction angiography, aortography and $C T$. As a CT scan provides significant information about the origin of systemic blood supply to the lung, it has been reported as the best non-invasive diagnostic method $(8,10)$. CT reconstruction techniques, like maximum intensity projection (MIP) and volume rendering (VR), provide further diagnostic information. These techniques enable the evaluation of finer anatomical details. MIP is a data visualization method that allows the detection of highly intense structures with respect to the surrounding tissues, such as vessels, nodules, calcifications, surgical clips and foreign bodies. A VR technique is used to evalvate different types of tissue, such as parenchyma, bone, airways and vessels, through an analysis of the data in a chosen Hounsfield range (13). We were unable to apply such techniques in the present case due to technical limitations. Aortic and pulmonary angiograms are advised in the formation of a treatment plan in symptomatic cases

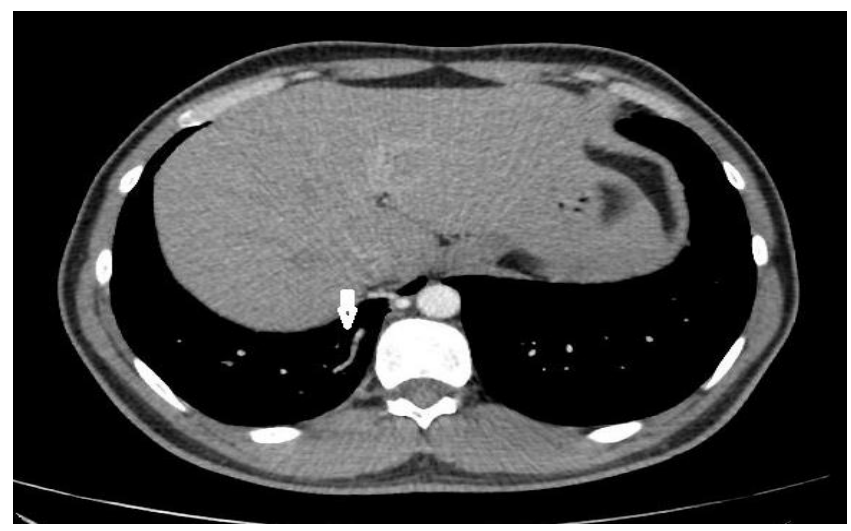

Figure 3: CT scan of the patient with hemoptysis or pulmonary hypertension. Our case was totally asymptomatic, and reported no previous pulmonary symptoms or diseases. This led us to suggest that the pseudosequestration was congenital, and so no further investigations were made.

Long-term antibiotic treatment for recurrent infections and coil embolization or lobectomy for hemoptysis have been reported as the treatments of choice in patients with acquired pseudosequestration $(5,10)$. Our case was diagnosed with congenital pseudosequestration, and was offered no treatment as he was asymptomatic. He was, however, advised to seek treatment should pulmonary symptoms develop.

\section{CONCLUSION}

Bronchopulmonary sequestrations are rare conditions, but can include a wide spectrum of abnormalities. In cases of non-functioning lung with an anomalous systemic blood supply, the patients are usually symptomatic with recurrent infections or hemoptysis, and are normally diagnosed in childhood or adolescence. In cases of a normal lung with an anomalous blood supply, however, the patient may be totally asymptomatic and may be diagnosed incidentally. We present here an interesting case with bronchopulmonary sequestration Pryce Type I or "pseudosequestration" to emphasize that asymptomatic congenital malformations may remain undiagnosed until adulthood.

\section{CONFLICTS OF INTEREST}

None declared.

\section{AUTHOR CONTRIBUTIONS}

Concept - N.E., S.B., S.K., B.S.; Planning and Design N.E., S..B., S.K., B.Ş.; Supervision - N.E., S..B., S.K., B.Ş.; Funding - N.E., S.B., S.K., B.S.; Materials - N.E., Ş.B., S.K.; Data Collection and/or Processing - N.E., S.B.; Analysis and/or Interpretation - N.E., S..B., B.Ş.; Literature Review - N.E., S..B.; Writing - N.E., S.B.; Critical Review N.E., S.B.

\section{YAZAR KATKILARI}

Fikir - N.E., Ş.B., S.K., B.Ş.; Tasarım ve Dizayn - N.E., S.B., S.K., B.S..; Denetleme - N.E., S..B., S.K., B.S.; Kaynaklar - N.E., S..B., S.K., B.S.; Malzemeler - N.E., Ş.B., S.K.; Veri Toplama ve/veya İşleme - N.E., Ş.B.; Analiz ve/veya Yorum - N.E., S..B., B.S.; Literatür Taraması N.E., S..B.; Yazıyı Yazan - N.E., Ş.B.; Eleştirel İnceleme N.E., S.B. 


\section{REFERENCES}

1. Pryce DM. Lower accessory pulmonary artery with intralobar sequestration of lung:A report of seven cases. J Pathol Bacteriol 1946; 58:457-67. [CrossRef]

2. Sade RM, Clouse M, Ellis FH Jr. The spectrum of pulmonary sequestration. Ann Thorac Surg 1974; 18:644-58. [CrossRef]

3. Clements BS, Warner JO. Pulmonary sequestrations and related congenital bronchopulmonary-vascular malformations: nomenclature and classification based on anatomical and embryological considerations. Thorax 1987; 42:401-8. [CrossRef]

4. Irodi A, Prabhu SM, John RA, Leena R. Congenital bronchopulmonary vascular malformations, sequestrations and beyond. Indian J Radiol Imaging 2015; 25:35-43. [CrossRef]

5. Singh AS, Subbain SK, Subramanian KG, Agarwal R, Dave DJ, Kulkarni $S$, et al. Pseudosequestration of the left lung. Tex Heart Int J 2007; 34:195-8.

6. Agarwal PP, Matzinger FR, Seely JM, Rasuli P, Shamii FM. An unusual case of systemic arterial supply to left lung with bronchial atresia. AJR Am J Roentgenol 2005; 185:150-3. [CrossRef]
7. Fernandez-Martorell P, Yoo SJ, Benson LN. An unusual form of anomalous systemic arterial supply to the left lung. Cardiol Young 2006; 16:305-7. [CrossRef]

8. Do KH, Goo JM, Im JG, Kim KW, Chung JW, Park JH. Systemic arterial supply to the lungs in adults: spiral CT findings. Radiographics 2001; 21:387-402. [CrossRef]

9. Irodi A, Cherian R, Keshava SN, James P. Dual arterial supply to normal lung: within the sequestration spectrum. Br J Radiol 2010; 83:e86-9. [CrossRef]

10. Matsuzono Y, Togashi T, Narita M, Taguchi Y, Miura S. Pulmonary aspergillosis and pseudosequestration of the lung in chronic granulomatous disease. Pediatr Radiol 1995; 25:201-3. [CrossRef]

11. Kirks DR, Kane PE, Free EA, Taybi H. Systemic arterial supply to normal basilar segments of the left lower lobe. AJR Am J Roentgenol 1976; 126:817-21. [CrossRef]

12. Boyden EA. Bronchogenic cysts and the theory of intralobar sequestration: new embryologic data. J Thorac Surg 1958; 35:604-15.

13. Perandini S, Faccioli N, Zaccarella A, Re T, Mucelli RP. The diagnostic contribution of $\mathrm{CT}$ volumetric rendering techniques in routine practice. Indian J Radiol Imaging 2010; 20:92-7. [CrossRef] 